\title{
Essence and Economical Substance of Innovative Cluster in Territorially Localized Business System
}

\author{
Ablaev I.M. \\ Khovanskaya E.S. \\ E-mail address: ildar_ablaev@mail.com, \\ Kazan Federal University, Kazan, 420008, Russia
}

\section{Doi:10.5901/mjss.2014.v5n12p159}

\begin{abstract}
The article describes different methodological; approaches to determine economical substance of innovative cluster on the level of regional economy of Russia from the point of view of foreign and Russian economists. The key elements of the notion of National innovative system on the basis of approaches of International organization of cooperation and development are determined.
\end{abstract}

Keywords: innovative cluster, national innovative system, levels of innovation, innovative modernization of the economy.

\section{Introduction}

During the last years growth rate of Russian economy had been constantly decreasing. If in 2007 there was growth on the level of 8,5\%, in 2008 it was 5,2\%, in crisis period of 2009 there was decrease of GDP for 7,8\%, slowdown continued in 2010, 2011, 2012, when growth was 4,5\%,4,3\%, 3,4\%, accordingly. Meanwhile acceleration of economic growth on the basis of qualitatively new model of development is necessary to solve social-economic problems of the country.

Modernization of the economy of the country as the most important necessary condition of transition of Russian economy to the innovative model of development should lead to increase of competitiveness of products of national industry. Manufacturers who are able to improve consumer properties of their goods continuously, to change production technology and to introduce new management methods become competitive. The above-mentioned processes cannot be implemented without inventors, researchers, creative workers, engineers, efficient managers who are able to apply new knowledge at work.

In the process of transition to the model of innovative modernization of economy development of regional innovative environment, where knowledge is transformed into a competitive product, becomes especially important .

Regulations intended to put the economy of the country on the innovative way, are issued on the level of president and government of the Russian Federation. But economic substance of innovations in regulations and economic literature is interpreted in different ways. Let's consider the main methodological approaches for innovations and define the boundaries of the concept in order to reveal the essence and economic contents of innovations.

\section{Theory}

Joseph Schumpeter greatly contributed to development of the notion "innovation". In his work "Theory of economic development" he analyses economics as iterative process in which every change in in definite frames. Developing this idea, he said that "there are changes that don't go on all the time, происходят не непрерывно, going beyond the usual frames, that change the usual course and that cannot be understood from the point of view of "circulation" [14]. These changes lead to development, to new qualitative state of the economy. According to Schumpeter, to produce means to combine things and forces available in our field. To produce something else or in other way means to create other combinations of these things and forces. Businessman-innovator as creator of new products, new markets, new technologies takes the central part in his theory. Schumpeter started to use the term "innovation" in the 30s of the XX century understanding this notion as change with the aim of introduction and use of new types of consumer goods, new manufacturing facilities and transportation assets, markets and forms of organization in the industry.

Innovation is the problem solving process процесc for the development of production and economy as a whole, 
while development, inventions, technologies and forms of organization of production are the means used at this. J. Schumpeter also says about this giving definition of innovation as the new combination of production factors.

It should be said that this is not an isolated case when innovations are regarded as the final product. L.A. Baev and V.E. Shugurov offered to divide the approaches to the definition of innovation into the following: object, process, objectpractical, process-practical and process-financial [4].

The essence of the object approach is that the object - the result of scientific and technical progress - serves as innovation: new techniques, technology or product. In the frames the process approach innovation is interpreted as complex process which includes development, manufacturing application and commercialization of new use values goods, technics, technology, organizational forms, etc. Object-practical and process-practical definitions disclose such characteristics of innovations as the ability to meet new requirements, to make economic profit. In the frames of the process-financial approach innovation is interpreted as process of investment into innovations, investing in the development of new techniques, technologies, researches.

In our opinion, both the object and process approaches can be used to the definition of innovations, depending on the objectives of the study.

In their research M. Porter and G. Bond single out upstream and downstream innovations. Upstream innovations are connected with scientific research and they create technological capabilities. Downstream innovations appear after the upstream ones, it is the process of commercialization of knowledge in the form of new products, new ways of organization of production and sales [3].

Began in 2008, the global economic crisis has systemic nature. Its main characteristics are the following:

- Concerning the reduction of economic and social indicators, the current crisis is comparable to the crises of the 1930s, 1970s.

- World crisis. Almost all countries of the world came under the influence of the crisis: developed, developing, countries with economy in transition.

- The crisis has affected all spheres of life of people: from the financial sector to the production of goods, social and political spheres.

- Duration of crisis. Beginning of the crisis was in 2007. Then it was a short period of economic recovery. However, currently the world economic growth is going down, and it is early to say about overcoming of crisis.

According to V. Mau [10], Glazyev [5] and other economists, the crisis is systemic, structural, caused, first of all, by deep technological shifts.

Wave nature of economic development is revealed in the works of N.D. Kondratyev. In the result of conjunctural waves study N.D. Kondratyev came to conclusion that necessity of renovation of "main capital goods" which does not occur smoothly as far as it requires the accumulation of resources, is the reason of uneven development of the economy [8]. From research Kondratyev singled out long waves in development of economy.

Approximation of the theory of large conjunctural cycles and the theory of innovation contributed to the division of innovations into the essential, improving ones. Gerhard Mensch in his book "Stalemate in technology: innovations overcome the depression" [2] revealed connections between basic innovations, economic growth and business cycle. According to his theory, the economy stagnates when potential of basic innovations is exhausted. He says that economy gets ready for new basic innovations at the stage of depression. To overcome the crisis it is necessary to accumulate "critical mass" of new knowledge in some economic sector or in related sectors, and innovation, followed by further investments, becomes the result of it. The process of implementation of basic innovations is replaced by the introduction of improving innovations, then time of pseudo innovations comes. G. Mensch describes "failures" of the market with applying the theory of "technological stalemate" of basic innovations in the following way: markets are not able to reorient resource flows of their "old" industrial sectors into the "new" ones; companies try to save expenditures for innovations; greater striving for short-term investments that prevents to make long-term decisions necessary for basic innovations.

The existence of exactly basic innovations makes the development of economy uneven. Consequently, basic innovations are the main factor of long wave. Glazy ev continues to study cycles of the economy, he sees the innovative replacement of capital as the way to overcome the crisis [5].

It is necessary to say about the theory "innovation pause hypothesis" [11], which is based on "general purpose technology" (GPT). The theory of GTP appeared in 1995. GTP is a technology which involves numerous improvements, has different variants of use, which is applicable in many economic sectors and which can be combined with other technologies, significantly increasing their efficiency (technological complementarity). Due to its properties GPT builds up a tree of new technologies, fundamentally changing the technological structure of the economy, preventing diminishing returns and thereby supporting economic growth [11].

Printing, the steam engine, electric motor, computer, internet are the examples of GPT. Effectiveness of each GPT 
decreases with time. If a new GPT does not come to substitute the old one, it causes slowdown of the economy and recession. This situation is called "innovative pause."

Robert Tucker divided innovations into three levels: "incremental innovations" - innovations that have little impact on corporate profits and which increase customer satisfaction from the product, for example, reducing service time due to the introduction of new systems; "significant innovations" - innovations that imply significant changes in the company's product line, that change the basic properties of goods, such as reduction of fuel consumption by vehicles; "breakthrough innovation" - "an epoch-making discovery", giant step on the way of humanity (for example, internet, car).

Thus, the innovation, on the one hand, is the cause of crisis, on the other hand, exactly the innovations are the basis for economic recovery and growth. The phase of the economic cycle - depression - is favorable period for the appearance and accumulation of basic innovations. It is explained by the fact that during the depression returns from using of the older technology becomes so low that it causes appearance of incentives for innovation, based on new developments.

V.E. Dementyev is one of the researchers of the cyclical nature of the economy. He also holds the opinion concerning structural nature of crisis. According to him, in the next decade developed countries will move on to formation of a new technological basis of economic systems based on the latest achievements in biotechnology, information technology and nanotechnology, including in public health service and other spheres [7].

On the basis of the above-mentioned approaches it is possible to make a conclusion about existence of three levels of innovation. The first level of innovations is in all industries all over the world, it's called "enhancing innovations". These innovations are manifested in the form of improvement of existing technologies and the products, works and services provided. Innovations that do not lead to drastic change of technology and the final product are on this level. In comparison with innovations of other levels they are manifested more regularly, and when considering the economy of the industrial sector, the region or the country as a whole we can say that they occur continuously.

The second level of innovation is represented by "radical innovations". The product characterized by new features, but which was created by old technology, is the result of radical innovations. In the terminology of R. Tucker they are called "significant innovations" [13].

The third level of innovation is the result of breakthrough technologies, change of technological structures. Discoveries in quantum physics, biotechnology, nanotechnology, etc., can be assigned to "revolutionary innovations". The introduction of such technology leads not only to rapid development of the economy, but also to more efficient use of resources, the emergence of new industries.

Thus, innovations are changes aimed at development or creation of new products, introduction of new production technology, a new method of introduction of goods into the market and further promotion, new forms of organization of production, the boundaries of which are limited between the first and third levels of innovation.

J. Kornai, examining innovation since 1917 (the appearance of the first socialist state - the USSR), came to the conclusion that "there was no any innovation" in the socialist system at all [9. 11] . In our opinion, it is not right to say about complete absence of innovation in the socialist countries is not true, as far as they include not only "revolutionary innovations", referred to the study. However, we should agree that the capitalist system generates innovations very successfully. The reason of it is in the special role of the above-mentioned businessman-innovator who cannot appear without business competition and within the frames of the centralized system.

Taking into account different points of view, we can highlight the main features of innovations that have been adopted by most researchers:

1. The requirement that the product, process, method of marketing or organization is a new one, is the characteristic of innovation;

2. We can say about innovation when new manufacturing processes, marketing methods or organizational methods are actually used in the activities of the company;

3. Economic benefit should be the goal of innovation.

It is commonly supposed that innovations exist within the national innovation system (NIS). National innovation system is interpreted as a set of enterprises of different forms of ownership, which - both individually, as well as in interaction with each other - provide the creation and expansion of new technologies within the country $[6,12]$. In case of such approach NIS participants are divided into 3 groups:

creators of ideas and inventions - research organizations: research institutes, universities, private laboratories, scientific departments of corporations, scientists, engineers, inventors;

- "infrastructural" enterprises: techno parks, innovation and technology centers, state corporations, venture capital funds; patent offices and agencies, ministries and departments that connect end users and creators of new knowledge; 
- consumers: small, medium and large business.

The notion "national innovative system" was introduced into science by C. Freeman, the English economist, the representative of neo-Schumpeter school in economic science. He understood NIS as the complex system of economic entities, business units and public institutions involved in creation, storage, expansion and transformation of new information into new technologies, products and services consumed by society $[1,13]$.

Within the framework of the Organization for Economic Cooperation and Development, the following definition is used: national innovation system is the whole complex of institutions which belong to private and public sectors that individually and in cooperation with each other - determine the development and expansion of new technologies within the country.

Thus, it is possible to determine the main institutions of NIS:

- state: legislation, system of education, budgetary system;

- organization of search and inventions: Research institutes, universities, laboratories, units of enterprises, where scientists, inventors, engineers work;

- $\quad$ "infrastructural" organizations: techno parks, innovation and technology centers, venture capital funds; patent offices and agencies, ministries and departments;

- representatives of business who create demand for innovations.

It is necessary to find organizational-economic form that will provide the introduction of scientific and technical developments in order to create an effective national innovation system. In our opinion, cluster can become such organizational - economic form.

\section{References}

Markov, V.A., Bagautdinova, N.G., Yashin, N.S. Improvement of instruments of the state cluster-based policy in the contexts of economic entities interrelation asymmetry // World Applied Sciences Journal, 27(13), 2013, 130-134.

Sarkin, A.V., Bagautdinova, N.G., Averianov, B.A. Development and implementation of adaptive science-intensive manufacture management system based on management processes automation // World Applied Sciences Journal, 27(13), 2013, 159-164.

Freeman C., Technology Policy and Economic Performance: Lessons from Japan, London: Frances Pinter, 2007.

Averianov, B.A., Bagautdinova, N.G., Sarkin, A.V. Estimation of manufacturing enterprise development risks in process of operational activity // World Applied Sciences Journal, 27(13), 2013, 202-206.

Mensch G. Stalemate in Technology. Cambridge, Mass: Ballinger Publishing Company, 1979.

Gainova R.A., Shaidullin R.N., Safiullin L.N. and Maratkanova E.M. Infrastructural Component in Maintenance of Competitiveness of Region// World Applied Sciences Journal, 27(13), 2013, pp. 97-101.

Safiullin M.R., Samigullin I.G. and Safiullin L.N. Model of Management of Competitiveness of a Machine-building Complex// World Applied Sciences Journal, 27(13), 2013, pp. 212-216.

Porter M., Bond G.C. Innovative Capacity and Prosperity. The Global Competitiveness Report. Geneva: Word Economic Forum, 2010.

Melnik A.N. The Organization of Russian Power Market in Modern Conditions / A.N. Melnik, O.N. Mustafina // Middle-East Journal of Scientific Research. - 2013. - v. 13 - pp. 91-94.

Askhatova L.I., Fatkhiev A.M., Safiullin L.N. and Safiullina A.M. Competitive Strategies Formation in High Technology Enterprise // World Applied Sciences Journal, 27(13), 2013, pp. 20-23.

Fakhrutdinova E.V., Kolesnikova J.S., Suleimanov T.D., Khalikov A.L. The interrelation of the problems of the youth labour market and the "brain drain". Life Science Journal 2014; 11(6s): $473-477$.

Karasik E., Yagudin R., Leukhin A., Zagidullina V. Improvement of social policy towards the disabled in the Russian Federation. Life Science Journal 2014; 11(6s): $478-481$.

Glebova I.S., Khabibrakhmanova R. and Yasnitskaya Y. The Analysis of the Impact of the Investment Attractiveness Factors of the Region on the Fixed Capital Investments in the Economy of the Republic of Tatarstan II Middle-East Journal of Scientific Research 17 (10): 1498-1502, 2013. 